$6060 \pm 120$ years B.P.

GGU 119524; K-1722. South-east shore of the head of Umîvit $\left(66^{\circ} 49^{\prime} 20^{\prime \prime} \mathrm{N}, 50^{\circ}\right.$ 45'30" W). Shell species: Mytilus edulis, Balanus sp., Hiatella arctica, Mya truncata, Macoma calcarea, Cardium sp.

The shells were collected from immediately below the surface of a marine terrace and from the surface of bedrock to which Balanus were still attached in life-like position 19-20 m a.s.l., and are considered to date a relative sea level $19-20 \mathrm{~m}$ above present sea level.

\title{
References
}

Beschel, R. 1961 : Dating rock surfaces by lichen growth and its application to glaciology and physiography (lichenometry). In Raasch, G. (editor) Geology of the Arctic 2, 1044-1062. Toronto U.P.

Sugden, D. E. 1969: Preliminary report of the Aberdeen University West Greenland Expedition 1968. Scott. geogr. Mag. 85, 105-108.

Weidick, A. 1968: Observations on some Holocene glacier fluctuations in West Greenland. Bull. Gronlands geol. Unders. 73 (also Meddr Gronland 165, 6) $202 \mathrm{pp}$.

Weidick, A. \& Ten Brink, N. W. 1969 : Quaternary deposits between the Sukkertoppen ice cap and Nordre Strømfjord. Rapp. Grønlands geol. Unders. 28, 23-25.

\section{FIELD WORK IN THE FISKENÆSSET AREA}

\section{F. Kalsbeek}

In 1969 GGU's base camp was moved from Mellembygden to Midgaard, some 15 km NNE of Fiskenæsset. In the summer of 1970 the systematic mapping of the Fiskenæsset area started. The following geologists took part in the mapping: L. Skov Andersen (Copenhagen), T. Frisch (Edmonton), A. M. Hopgood (St. Andrews), T. C. R. Pulvertaft (GGU), G. Rivalenti (Modena), J. R. Tomas (Prague), B. J. Walton (Portsmouth), H. R. Williams (Exeter) and B. F. Windley (Leicester). A special study of the sapphirine localities known in the area was made by R. K. Herd (Leicester). The field groups were organised much as in earlier years. Every geologist had an assistant. Transport was supplied by two Bell $47 \mathrm{~J}$ helicopters and two GGU cutters. Most of the practical arrangements were made by Ib Olsen of GGU.

Most of the area covered this summer, roughly situated between Frederikshåb Isblink and Fiskenæsset $\left(62^{\circ} 40^{\prime}-63^{\circ} 10^{\prime} \mathrm{N}\right)$, consists of fairly uniform gneisses which locally are slightly banded and which contain bands and lenses of amphibolite. 
Within these gneisses the meta-anorthosites and associated rocks of the Fiskenæsset complex occur (Ghisler \& Windley, 1967). The anorthositic rocks generally vary in thickness from $100 \mathrm{~m}$ to $1 \mathrm{~km}$, but they may reach thicknesses of up to $2 \mathrm{~km}$ and they may thin out almost completely so that they are only found as lenses in the surrounding gneiss, and horizons containing anorthositic lenses may be followed over many kilometres. The anorthosite complex serves as an excellent marker unit and shows a very intricate pattern of folding which often cannot be recognised in the surrounding gneisses. These features are especially well developed in the area around Kangârssuk and Siggartartulik mapped by Pulvertaft. Windley has been able to establish a stratigraphy in the anorthosite complex (Windley, this report) and it can be shown that often the complex is built up symmetrically. This indicates that at many places the anorthosite complex is part of a tightly compressed isocline, and this has been confirmed by the mapping of a few closures of these folds in the field.

The fieldwork has cast doubt on the earlier opinion that the pyribolites and ultramafic rocks, which often fringe the anorthosite complex, actually belong to the complex.

Minor occurrences of anorthositic rocks have been found by Williams as far east as the margin of the Inland Ice east of Bjørnesund.

The origin of the gneisses in the area has been much under debate during the field work. There is little evidence on which to decide whether they represent old granitic rocks or (in part) old metasediments. The occurrence of marble layers in the gneisses, found by Hopgood, may indicate that at least part of the gneisses are metasedimentary in origin. Minor occurrences of marble have also been found in gneisses by Rivalenti, and Heard noted marble in two sapphirine localities.

The metamorphic grade of the rocks gradually decreases from north to south. Around Midgaard most rocks belong to the granulite facies. South of Fiskenæsfjorden amphibolite facies rocks prevail, but locally granulite facies rocks occur. As far south as Bjørnesund hypersthene gneisses have been found by Walton and Tomas.

In the extreme southern part of the area, mapped by Skov Andersen, epidote becomes locally common in the gneisses and the rocks may belong to the epidoteamphibolite facies. Skov Andersen has started a detailed investigation of the lowgrade rocks of the Ravns Storø greenschist belt, but the relationship of the low-grade rocks to the surrounding gneisses is not yet quite understood.

\section{Reference}

Ghisler, M. \& Windley, B. F. 1967: The chromite deposits of the Fiskenæsset region, West Greenland. Rapp. Gronlands geol. Unders. 12, 38 pp. 